\title{
Latex-induced occupational asthma
}

\section{To the Editor:}

The European Respiratory Journal's series on "Occupational Asthma" gives an excellent overview of this important topic in modern pneumology. In particular, the contribution by CHAN-YEUNG and MALO [1], with its appendix listing the many potential causes of occupational asthma, will no doubt prove a very useful source of information. It is, however, a little surprising that an important and increasingly frequent cause of occupational asthma, such as latex, was not considered in the main text and not listed correctly in the appendix.

Sensitization to latex (or natural rubber) is an important cause of occupational allergic reactions, including urticaria, rhinitis, conjunctivitis and/or asthma, particularly in rubber industry workers and in health-care or other personnel having to wear latex gloves. Life-threatening anaphylactic reactions have also been described in sensitized individuals exposed to latex outside their work, e.g. through medical, gynaecological or surgical procedures; thus, emphasizing the importance of a correct recognition of the sensitization. The consensus is that these immediate hypersensitivity reactions occur via immunoglobulin $\mathrm{E}$ ( $\mathrm{IgE}$ )-dependent mechanisms directed against proteins from Hevea brasiliensis, the rubber-producing tree [2]. These rubber allergens easily become airborne, as they are absorbed onto the cornstarch powder generally used to lubricate the gloves.
It would, therefore, seem appropriate to include latex in the category of "High Molecular Weight Compounds - Plant Proteins", rather than in a category of widely differing "Chemicals", as was done in the table in the article of CHAN-Yeung and Malo [1].

\section{B. Nemery}

Laboratory of Pneumology, K.U. Leuven, Leuven, Belgium

\section{REPLY}

From the authors:

B. Nemery raised an important point about latex-induced occupational asthma. We agree entirely with him that latex should be classified under the "High Molecular Weight Compounds - Plant Proteins". We will take this into consideration when we next revise the tables and the text.

M. Chan-Yeung, J-L Malo

UBC Respiratory Division, Main Floor, 2778 Heather Street, Vancouver General Hospital, Vancouver BC, Canada 
